\title{
Synthesis, Structural Characterization, and Evaluation of the Biological Properties of Heteroleptic Palladium(II) Complexes
}

\author{
Hizbullah Khan, ${ }^{1}$ Nek Daraz, ${ }^{1}$ Muhammad Nasim Khan, ${ }^{2}$ Muhammad Said, ${ }^{3}$ \\ Nosheen Akhtar, ${ }^{1}$ Amin Badshah, ${ }^{4}$ Amir Sada Khan, ${ }^{1,5}$ and Murad Ali ${ }^{2}$ \\ ${ }^{1}$ Department of Chemistry, University of Science and Technology, Bannu 28100, Pakistan \\ ${ }^{2}$ Department of Chemistry, Kohat University of Science and Technology, Kohat 26000, Pakistan \\ ${ }^{3}$ Department of Chemistry, Abdul Wali Khan University, Mardan 23200, Pakistan \\ ${ }^{4}$ Department of Chemistry, Quaid-i-Azam University, Islamabad 45320, Pakistan \\ ${ }^{5}$ PETRONAS Ionic Liquid Centre, Department of Chemical Engineering, Universiti Teknologi Petronas, \\ Seri Iskandar, 31750 Tronoh, Perak, Malaysia \\ Correspondence should be addressed to Hizbullah Khan; hizbmarwat@yahoo.com
}

Received 6 May 2014; Revised 15 July 2014; Accepted 18 July 2014; Published 7 September 2014

Academic Editor: Francesco P. Fanizzi

Copyright (C) 2014 Hizbullah Khan et al. This is an open access article distributed under the Creative Commons Attribution License, which permits unrestricted use, distribution, and reproduction in any medium, provided the original work is properly cited.

Five heteroleptic palladium(II) complexes of the general formula $\mathrm{Pd}\left(\mathrm{PR}_{3}\right)(\mathrm{tu}) \mathrm{Cl}_{2}$, where $\mathrm{PR}_{3}=$ triphenylphosphine (1), diphenyl-otolylphosphine (2), diphenyl-p-tolylphosphine (3), diphenyl-t-butylphosphine (4), and diphenyl-o-methoxyphenylphosphine (5), and tu $=1,3$-bis(2-methoxyphenyl) thiourea. They all have been synthesized and characterized by various spectroscopic techniques (elemental analysis, FTIR, and ${ }^{1} \mathrm{H}$ NMR and the ligand 1,3-bis(2-methoxyphenyl) thiourea was synthesized by single crystal X-ray diffraction technique). The synthesized compounds were screened for their antibacterial activity against four strains of bacteria (Escherichia coli, Shigella flexneri, Staphylococcus aureus, and Bacillus subtilis). The antitumor potential was evaluated in terms of activity against brine shrimp eggs and DNA interaction. The mixed ligand complexes have exhibited moderate antibacterial activity and promising antitumor potential.

\section{Introduction}

Metals medicinal applications are almost several hundred years old. But due to the lack of experience of pharmacologists and traditional medicinal chemists in dealing with biologically active metal complexes, the field of metal-based drugs could not flourish at the desired rate. However, it provides an opportunity to transition metal chemists to establish the development of exciting new drugs [1-5]. With the improvement in the understanding of metalloprotein function, some outstanding models of metal ion active sites and recent advances in discovering how naturally occurring metal ions are delivered to these active sites, and how metal ions are complexed in the reduction of some diseases; specify new roles for metal ions in curative strategies [6-10]. Although some nonmetal species like tamoxifen and taxol also show biological functions, it is clear that a major role is played by metal ions in biochemical process. Metal ions are considered to exert an inductive effect by coordination to the site of reaction and they work as reduction-oxidation sites that function either through electron or atom transfer [11-14]. The present development of successful metal based pharmaceuticals, which include the platinum anticancer drugs and radiodiagnostic agents, shows the usefulness of complexes as both diagnostic and therapeutic agents [15-19]. Cancer is one of the diseases that are responsible for the high death rate globally. Consequently, there has been a great need for continuous research to synthesize new drugs to control this disease.

During the mid-1970s, initial antitumor studies with cisdiamminedichloroplatinum(II) (cisplatin) indicated significant activity against some of the cancer cell-lines, especially leukemia L1210 tumors. Cisplatin remains to be the most effective drug in clinical treatment for ovarian, testicular, bladder, head, and neck cancers. In combination with other 


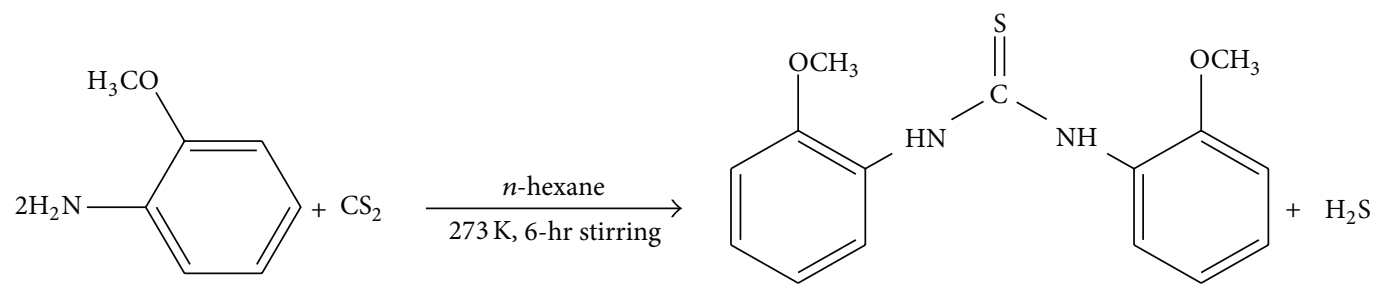

SCHeme 1: Synthesis of the substituted thiourea.

anticancer drugs such as doxorubicin, and 5-fluorouracil, it is widely used in treatment of neck cancer. However, there is a built-in and acquired resistance that limits the clinical usefulness of the drug. Platination of DNA is considered to be responsible for the antitumor activity of various platinum containing drugs through bonding to guanine $[20,21]$. Palladium(II) analogues are structurally similar to those of $\mathrm{Pt}$ (II) complexes which have a very similar coordination geometry and coordination process [22-24]. Generally, $\mathrm{Pt}(\mathrm{II})$ complexes are less stable than $\mathrm{Pd}(\mathrm{II})$ compounds. Therefore, $\mathrm{Pd}(\mathrm{II})$ systems are frequently used as model complexes [25]. $\mathrm{Pd}(\mathrm{II})$ binding to the guanine ring has been proposed from IR and NMR data in several models. The models reveal coordination with $\mathrm{C}=\mathrm{O}-\mathrm{Pd}-\mathrm{N}_{7}$ bridge between adjacent guanine rings and chelation through $\mathrm{N}_{7}$ and $\mathrm{C}=\mathrm{O}$ of a guanine ring [26].

We report here the synthesis, spectral characterization, and biological activities of the heteroleptic $\mathrm{Pd}(\mathrm{II})$ complexes of the general formula $\mathrm{Pd}\left(\mathrm{PR}_{3}\right)(\mathrm{tu}) \mathrm{Cl}_{2}$, where $\mathrm{PR}_{3}=$ triphenylphosphine (1), diphenyl-o-tolylphosphine (2), diphenyl- $p$ tolylphosphine (3), diphenyl-t-butylphosphine (4), and diphenyl-o-methoxyphenylphosphine (5); tu = 1,3-bis(2-methoxyphenyl) thiourea.

\section{Experimental}

2.1. Materials and Methods. Ethanol, methanol, n-hexane, fish sperm DNA, dichloromethane, chloroform, carbon disulfide and $\mathrm{PdCl}_{2}$, sea salt, and brine shrimp eggs were obtained from Merck Germany and Sigma-Aldrich. All the solvents and chemicals were of analytical grade and were used as received, without further purification.

2.2. Synthesis of the Substituted Thiourea. Substituted thiourea was synthesized by the reaction of $o$-methoxyphenylamine with carbon disulphide $(2: 1)$, respectively, at 273 Kelvin in $n$-hexane, as shown in Scheme 1, by the reported literature method with slight modification [27]. The reaction mixture was magnetically stirred for six hours and the reaction progress was continuously monitored by thin layer chromatography. The solvent was evaporated under the reduced pressure and the light brown solid was dissolved in a mixture of dichloromethane and $n$-hexane $(2: 1 \mathrm{v} / \mathrm{v})$ for recrystallization. Needle shaped light brown crystals were obtained by the slow evaporation of the solvents at room temperature, and a suitable crystal was separated for single crystal diffraction analysis.
2.3. Synthesis of the Complexes (1-5). The mixed ligand $\mathrm{Pd}(\mathrm{II})$ complexes were synthesized in two steps [28]. In the first step, Pd-organophosphine complex was formed by reacting organophosphine ligand, dissolved in acetone, with palladium chloride dissolved in dry methanol and few drops of concentrated hydrochloric acid in 2:1 molar ratio. The solid golden yellow product was obtained by evaporating the reaction mixture at reduced pressure. In the second step, the golden yellow product was dissolved in dichloromethane and was reacted with 1,3-bis(2-methoxyphenyl) thiourea solution in dichloromethane in 1:1 molar ratio. The final heteroleptic $\mathrm{Pd}(\mathrm{II})$ complex was obtained by rotary evaporation of the reaction mixture.

2.3.1. $\left[\mathrm{Pd}\left(1,3-\right.\right.$ bis(2-methoxyphenyl) thiourea) $\left.\left(\mathrm{PPh}_{3}\right) \mathrm{Cl}_{2}\right]$ (1). Quantities used were $0.32 \mathrm{~g}(0.47 \mathrm{mmol})$ of $\mathrm{Pd}\left(\mathrm{PPh}_{3}\right)_{2} \mathrm{Cl}_{2}$ and $0.15 \mathrm{~g}(0.47 \mathrm{mmol})$ of 1,3 -bis $(2$-methoxyphenyl) thiourea in $25 \mathrm{~mL}$ of dichloromethane. Yield: $0.29 \mathrm{~g}$ (87\%). M.p.: 231$232^{\circ} \mathrm{C}$. FTIR (powder, $\mathrm{cm}^{-1}$ ): $3316 v(\mathrm{~N}-\mathrm{H}), 1122 v(\mathrm{C}-\mathrm{N}), 622$ $v(\mathrm{C}=\mathrm{S}), 2831 v(\mathrm{C}-\mathrm{H}$, aliphatic $)$, and $2943 v(\mathrm{C}-\mathrm{H}$, aromatic $)$. ${ }^{1} \mathrm{H}$ NMR $\left(300 \mathrm{MHz}, \mathrm{CDCl}_{3}\right) \delta$-ppm: $3.72\left(\mathrm{~s}, 3 \mathrm{H},-\mathrm{OCH}_{3}\right)$, $4.05(\mathrm{~s}, 2 \mathrm{H},-\mathrm{NH})$, and 6.35-7.59 (m, 23H, Ar-H). Anal. Calc. for $\mathrm{C}_{33} \mathrm{H}_{31} \mathrm{Cl}_{2} \mathrm{~N}_{2} \mathrm{O}_{2}$ PPdS: C, 54.45; $\mathrm{H}, 4.29 ; \mathrm{N}, 3.85 ; \mathrm{S}, 4.40$. Found: C, 54.50; H, 4.26; N, 3.87; S, 4.40.

2.3.2. $\left[P d(1,3-b i s(2-m e t h o x y p h e n y l)\right.$ thiourea $)\left(P P h_{2}\right.$-o-tolyl) $\mathrm{Cl}_{2}$ ] (2). Quantities used were $0.35 \mathrm{~g}(0.47 \mathrm{mmol})$ of $\mathrm{Pd}$ $\left(\mathrm{PPh}_{2} \text {-o-tolyl }\right)_{2} \mathrm{Cl}_{2}$ and $0.15 \mathrm{~g}(0.47 \mathrm{mmol})$ of 1,3 -bis(2-methoxyphenyl) thiourea in $25 \mathrm{~mL}$ of dichloromethane. Yield: $0.30 \mathrm{~g}$ (85\%). M.p.: $237-238^{\circ} \mathrm{C}$. FTIR (powder, $\mathrm{cm}^{-1}$ ): 3313 $v(\mathrm{~N}-\mathrm{H}), 1022 v(\mathrm{C}-\mathrm{N}), 633 v(\mathrm{C}=\mathrm{S}), 2832 v(\mathrm{C}-\mathrm{H}$, aliphatic $)$, and $2942 v\left(\mathrm{C}-\mathrm{H}\right.$, aromatic). ${ }^{1} \mathrm{H}$ NMR $\left(300 \mathrm{MHz} \mathrm{CDCl}_{3}\right) \delta$ ppm: 2.33 (s, 3H, $\left.-\mathrm{CH}_{3}\right), 3.75\left(\mathrm{~s}, 3 \mathrm{H},-\mathrm{OCH}_{3}\right), 4.00(\mathrm{~s}, 2 \mathrm{H}$, $-\mathrm{NH})$, and 6.33-7.63 (m, 22H, Ar-H). Anal. Calc. for $\mathrm{C}_{34}$ $\mathrm{H}_{33} \mathrm{Cl}_{2} \mathrm{~N}_{2} \mathrm{O}_{2}$ PPdS: C, 55.03; H, 4.48; N, 3.78; S, 4.32. Found: C, 55.10; H, 4.47; N, 3.78; S, 4.33.

2.3.3. $\left[P d(1,3-b i s(2-m e t h o x y p h e n y l)\right.$ thiourea $)\left(P P h_{2}-p\right.$-tolyl) $\mathrm{Cl}_{2}$ ] (3). Quantities used were $0.34 \mathrm{~g}(0.47 \mathrm{mmol})$ of $\mathrm{Pd}$ $\left(\mathrm{PPh}_{2} \text {-p-tolyl }\right)_{2} \mathrm{Cl}_{2}$ and $0.15 \mathrm{~g}(0.47 \mathrm{mmol})$ of 1,3 -bis(2-methoxyphenyl) thiourea in $25 \mathrm{~mL}$ of dichloromethane. Yield: $0.32 \mathrm{~g}$ (91\%). M.p.: $248-249^{\circ} \mathrm{C}$. FTIR (powder, $\mathrm{cm}^{-1}$ ): 3318 $v(\mathrm{~N}-\mathrm{H}), 1021 v(\mathrm{C}-\mathrm{N}), 640 v(\mathrm{C}=\mathrm{S}), 2832 v(\mathrm{C}-\mathrm{H}$, aliphatic $)$, and $2944 v\left(\mathrm{C}-\mathrm{H}\right.$, aromatic). ${ }^{1} \mathrm{H} \mathrm{NMR}\left(300 \mathrm{MHz}, \mathrm{CDCl}_{3}\right)$ $\delta$-ppm: $2.34\left(\mathrm{~s}, 3 \mathrm{H},-\mathrm{CH}_{3}\right), 3.70\left(\mathrm{~s}, 3 \mathrm{H},-\mathrm{OCH}_{3}\right), 4.02(\mathrm{~s}$, $2 \mathrm{H},-\mathrm{NH})$, and 6.30-7.65 (m, 22H, Ar-H). Anal. Calc. for 
$\mathrm{C}_{34} \mathrm{H}_{33} \mathrm{Cl}_{2} \mathrm{~N}_{2} \mathrm{O}_{2}$ PPdS: C, 55.03; H, 4.48; N, 3.78; S, 4.32. Found: C, 55.09; H, 4.44; N, 3.77; S, 4.29.

2.3.4. $\left[P d(1,3-b i s(2-m e t h o x y p h e n y l)\right.$ thiourea $)\left(P P h_{2}\right.$-t-butyl) $\mathrm{Cl}_{2}$ ] (4). Quantities used were $0.31 \mathrm{~g}(0.47 \mathrm{mmol})$ of $\mathrm{Pd}$ $\left(\mathrm{PPh}_{2}-t \text {-butyl }\right)_{2} \mathrm{Cl}_{2}$ and $0.15 \mathrm{~g}(0.47 \mathrm{mmol})$ of 1,3 -bis(2-methoxyphenyl) thiourea in $25 \mathrm{~mL}$ of dichloromethane. Yield: $0.27 \mathrm{~g}$ (81\%). M.p.: 269-270 C. FTIR (powder, $\mathrm{cm}^{-1}$ ): 3321 $v(\mathrm{~N}-\mathrm{H}), 1023 v(\mathrm{C}-\mathrm{N}), 647 v(\mathrm{C}=\mathrm{S}), 2831(\mathrm{C}-\mathrm{H}$, aliphatic), and $2945 v\left(\mathrm{C}-\mathrm{H}\right.$, aromatic). ${ }^{1} \mathrm{H}$ NMR $\left(300 \mathrm{MHz}, \mathrm{CDCl}_{3}\right)$ $\delta$-ppm: $2.42\left(\mathrm{~s}, 9 \mathrm{H},-\mathrm{C}\left(\mathrm{CH}_{3}\right)_{3}\right), 3.69\left(\mathrm{~s}, 3 \mathrm{H},-\mathrm{OCH}_{3}\right), 4.01$ (s, 2H, -NH), and 6.37-7.35 (m, 18H, Ar-H). Anal. Calc. for $\mathrm{C}_{31} \mathrm{H}_{35} \mathrm{Cl}_{2} \mathrm{~N}_{2} \mathrm{O}_{2} \mathrm{PPdS}$ : C, 52.58; $\mathrm{H}, 4.98 ; \mathrm{N}, 3.96 ; \mathrm{S}, 4.52$. Found: C, 52.49; H, 4.97; N, 3.96; S, 4.51.

2.3.5. $\left[P d(1,3-b i s(2-m e t h o x y p h e n y l)\right.$ thiourea $)\left(P P h_{2}-o-m e t h o-\right.$ xyphenyl) $\mathrm{Cl}_{2}$ ] (5). Quantities used were $0.36 \mathrm{~g}(0.47 \mathrm{~mm}$ ol) of $\mathrm{Pd}\left(\mathrm{PPh}_{2}-t \text {-butyl }\right)_{2} \mathrm{Cl}_{2}$ and $0.15 \mathrm{~g}(0.47 \mathrm{mmol})$ of $1,3-$ bis(2-methoxyphenyl) thiourea in $25 \mathrm{~mL}$ of dichloromethane. Yield: $0.30 \mathrm{~g}(84 \%)$. M.p.: $252-253^{\circ} \mathrm{C}$. FTIR (powder, $\left.\mathrm{cm}^{-1}\right): 3328 v(\mathrm{~N}-\mathrm{H}), 1022 v(\mathrm{C}-\mathrm{N}), 636 v(\mathrm{C}=\mathrm{S}), 2835 v(\mathrm{C}-\mathrm{H}$, aliphatic), and $2946 v\left(\mathrm{C}-\mathrm{H}\right.$, aromatic). ${ }^{1} \mathrm{H}$ NMR $(300 \mathrm{MHz}$, $\left.\mathrm{CDCl}_{3}\right) \delta$-ppm: $3.70\left(\mathrm{~s}, 9 \mathrm{H},-\mathrm{OCH}_{3}\right)$ and $4.01(\mathrm{~s}, 2 \mathrm{H},-\mathrm{NH})$. Anal. Calc. for $\mathrm{C}_{31} \mathrm{H}_{35} \mathrm{Cl}_{2} \mathrm{~N}_{2} \mathrm{O}_{2}$ PPdS: C, 53.87; $\mathrm{H}, 4.39 ; \mathrm{N}$, 3.70; S, 4.23. Found: C, 53.75; H, 4.38; N, 3.69; S, 4.20.

2.4. Structural Study of the Ligand 1,3-Bis(2-methoxyphenyl) Thiourea. The crystal structure of the thiourea derivative was developed by the evaporation method, from the solvent of methanol. Colorless needle shaped crystals were obtained after slow evaporation of the solvent from a methanolic solution of the ligand at room temperature. The needle shaped crystal was mounted on a glass fiber using epoxy glue. The measurements were made at $293 \mathrm{~K}$ on a Bruker APEX II area detector diffractometer equipped with graphite monochromatic Mo-K $\alpha$ radiation $(0.71073 \AA)$. The programme used for retrieving the cell parameters and data collection was APEX [29]. The data were integrated using the programme SAINT [30] and were corrected for Lorentz and polarization effects. The structure was solved and refined using SHELXS97 and SHELXL-97 [31]. All the non-H atoms were refined anisotropically. The hydrogen atoms were placed at the idealized positions. The crystal data and structure refinement parameters are shown in Table 1.

\subsection{Biological Assays}

2.5.1. Antibacterial Assay. All the synthesized metal complexes were investigated for their antibacterial activity against four strains of bacteria (Escherichia coli, Shigella flexneri, Staphylococcus aureus, and Bacillus subtilis). The agar well diffusion method [32] was used to determine the inhibition zone and minimum inhibitory concentration (MIC). Broth culture $(0.70 \mathrm{~mL})$ containing ca., $10^{6}$ colony forming units (CFU) per $\mathrm{mL}$ of the test strain was added to $70 \mathrm{~mL}$ of nutrient agar medium at $45^{\circ} \mathrm{C}$, mixed well, and then poured into a $14 \mathrm{~cm}$ diameter sterile petri plate. The media was allowed to solidify and $8 \mathrm{~mm}$ wells were dug by a sterile metallic borer.
TABLE 1: Crystal data and details of the structure refinement of the ligand 1,3-bis(2-methoxyphenyl) thiourea.

\begin{tabular}{lc}
\hline Molecular formula & $\mathrm{C}_{15} \mathrm{H}_{16} \mathrm{~N}_{2} \mathrm{O}_{2} \mathrm{~S}$ \\
Molecular weight & 288.36 \\
Space group & $\mathrm{C}_{2} / \mathrm{c}$ \\
& $\mathbf{a}: 14.442$ \\
Cell lengths $(\AA)$ & $\mathbf{b}: 13.032$ \\
& $\mathbf{c : ~} 16.187$ \\
Cell angles $\left(^{\circ}\right)$ & $\boldsymbol{\alpha}: 90.00$ \\
& $\boldsymbol{\beta}: 103.89$ \\
Cell volume $(\AA)^{3}$ & $\gamma: 90.00$ \\
Z, Z & 2957.44 \\
$R$-factor $(\%)$ & $\mathrm{Z}: 8$ \\
Temperature & $\mathrm{Z}^{\prime}: 0$ \\
Wavelength & 2.91 \\
\hline
\end{tabular}

DMSO test sample $(100 \mu \mathrm{L})$ at $1 \mathrm{mg} / \mathrm{mL}$ was added to the respective wells. DMSO was acting as a negative control, while the standard drug Imipenem $(10 \mu \mathrm{g} /$ disc $)$ was used as a positive control. Triplicate plates of each bacterial strain were prepared and incubated aerobically at $37^{\circ} \mathrm{C}$ for 24 hours. The activity was determined by measuring the diameter of zone $(\mathrm{mm})$ with the aid of a Vernier Caliper (precision $\pm 0.1 \mathrm{~mm})$. The growth inhibition was calculated with reference to the positive control.

2.5.2. Cytotoxicity Screenings. Stock solutions of the compounds were prepared by dissolving $5 \mathrm{mg} / 5 \mathrm{~mL}$ in methanol. From the stock solution three other solutions of $50 \mu \mathrm{g} / \mathrm{mL}$, $100 \mu \mathrm{g} / \mathrm{mL}$, and $500 \mu \mathrm{g} / \mathrm{mL}$ concentrations were prepared by using the dilution formula. As the assay was carried out in duplicate, each solution was divided into two parts thus preparing three other solutions, $50 \mu \mathrm{g} / \mathrm{mL}, 100 \mu \mathrm{g} / \mathrm{mL}$, and $500 \mu \mathrm{g} / \mathrm{mL}$, respectively. Two test tubes for control were also prepared having only $5 \mathrm{~mL}$ of media.

An amount of $2.8 \mathrm{~g}$ of sea salt was dissolved in $100 \mathrm{~mL}$ of distilled water $(2.8 \mathrm{~g} / 100 \mathrm{~mL})$ and put on the magnetic stirrer for two hours. A rectangular tray having many pores in its partition was taken for hatching the shrimps. The media and shrimp eggs were put in the tray covered with aluminum foil provided with an air pump. After 24 hours incubation (using table lamp), the larvae were shifted from the darkened side to the open portion of the tray. The larvae were collected by poster pipette.

A volume of $0.5 \mathrm{~mL}(500 \mu \mathrm{L})$ of each solution was taken in a separate test tube labeled as $50 \mu \mathrm{g} / \mathrm{mL}, 100 \mu \mathrm{g} / \mathrm{mL}$, and $500 \mu \mathrm{g} / \mathrm{mL}$, and eight larvae were transferred to each test tube with the help of a poster pipette dropper. The solution was made $5 \mathrm{~mL}$ by the addition of media. A separate test tube containing only $5 \mathrm{~mL}$ media was also taken and labelled as control. After taking all the necessary measures, each test tube was tightly packed with cotton and incubated at $28^{\circ} \mathrm{C}$ for 24 hours. After 24 hours incubation, the number of living 


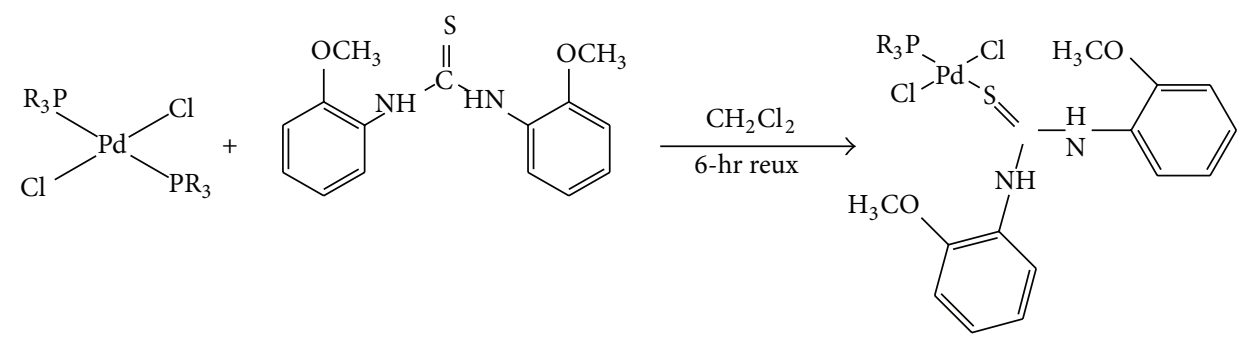

Scheme 2: Synthesis of heteroleptic Pd(II) complexes.

TABle 2: Antibacterial activity of the complexes (in vitro) against four different bacterial pathogens (diameter of inhibition zone in $\mathrm{mm})$.

\begin{tabular}{lcccc}
\hline Sample codes & E. coli & B. subtilis & S. flexneri & S. aureus \\
\hline $\mathbf{1}$ & 18 & 19 & 20 & 23 \\
$\mathbf{2}$ & 19 & 17 & 15 & 22 \\
$\mathbf{3}$ & 14 & 14 & 18 & 18 \\
$\mathbf{4}$ & 18 & 13 & 16 & 24 \\
$\mathbf{5}$ & 20 & 17 & 19 & 25 \\
Standard Drug, & 30 & 32 & 35 & 40 \\
Imipenem & & & & \\
\hline
\end{tabular}

Conc. of the standard drug "Imipenem" $=10 \mu \mathrm{g} / \mathrm{disc}$.

Concentration of sample $=5 \mathrm{mg} / \mathrm{mL}$ (stock solution) and $10 \mu \mathrm{g} / \mathrm{disc}$.

shrimps was counted and calculations were made by using Abbot's formula and the results are shown in Table 3

$$
\% \text { death }=\left(\text { control }-\frac{\text { sample }}{\text { control }}\right) \times 100 \text {. }
$$

2.6. Absorption Spectroscopy. At room temperature, absorption spectra were recorded on Shimadzu UV-1800 Koyoto Japan. Standard quartz cells of $1-\mathrm{cm}$ path length were used. The concentration of the complex solution was kept constant at $2 \mu \mathrm{M}$, while the concentration of the DNA solution was changed, by $20 \mu \mathrm{L}$ after each addition, in such a way that the total volume of the blank and the complex was constant. The change in the absorption spectra of the complexes with the increasing concentration of the DNA is shown in Table 4.

\section{Results and Discussions}

3.1. Structural Study of the Ligand 1,3-Bis(2-methoxyphenyl) Thiourea. The capped sticks diagram of the substituted thiourea with selected bond lengths and angles is shown in Figure 1. The carbon atom in $\mathrm{N}-\mathrm{C}=\mathrm{S}$ moiety of the ligand is $\mathrm{sp}^{2}$ hybridized. The compound crystallizes in $\mathrm{C}_{2} / \mathrm{c}$ space group. The $\mathrm{C}_{8}-\mathrm{S}_{1}$ bond length, $1.690(2) \AA$ is greater than $\mathrm{C}=\mathrm{S}$ double bond $(1.60 \AA)$, but shorter than $\mathrm{C}-\mathrm{S}$ single bond $(1.82 \AA)$ distance $[33,34]$. The torsion angle measurements show that $\mathrm{C}_{1} \mathrm{O}_{1} \mathrm{C}_{2} \mathrm{C}_{3}$ are almost planar with the torsion angle of $-2.3(3)^{\circ}$. Similarly, the other methoxy group is lying in more planarity with the aromatic ring with the torsion angle of $-1.1(3)^{\circ}\left(\mathrm{C}_{15} \mathrm{O}_{2} \mathrm{C}_{14} \mathrm{C}_{13}\right)$.
TABLE 3: The number of surviving shrimps after 24 hours incubation in the complexes and control.

\begin{tabular}{lccccc}
\hline Compounds & $\begin{array}{c}50 \\
\mu \mathrm{g} / \mathrm{mL}\end{array}$ & $\begin{array}{c}100 \\
\mu \mathrm{g} / \mathrm{mL}\end{array}$ & $\begin{array}{c}500 \\
\mu \mathrm{g} / \mathrm{mL}\end{array}$ & Control & $\begin{array}{c}\text { Mean } \% \\
\text { death }\end{array}$ \\
\hline $\mathbf{1}$ & 6 & 5 & 2 & 8 & $45.83 \pm 21.24$ \\
$\mathbf{2}$ & 3 & 1 & 0 & 8 & $83.33 \pm 15.60$ \\
$\mathbf{3}$ & 5 & 3 & 2 & 8 & $45.83 \pm 25.12$ \\
$\mathbf{4}$ & 4 & 3 & 2 & 8 & $70.83 \pm 13.17$ \\
$\mathbf{5}$ & 7 & 4 & 3 & 8 & $41.67 \pm 21.24$ \\
\hline
\end{tabular}

3.2. Synthesis of the Complexes and Their Characterization. Mixed ligand Pd(II) complexes were synthesized by reacting substituted thiourea ligand with the palladium phosphine complexes as shown in Scheme 2.

3.3. Infrared Spectroscopy. According to the literature, tentative assignments were made [35] and the appearance of the signal in the range of $3313-3328 \mathrm{~cm}^{-1}$ demonstrates the presence of $\mathrm{N}-\mathrm{H}$ group in the complexes. The IR peak in the range of $1021-1122 \mathrm{~cm}^{-1}$ confirms the $\mathrm{C}-\mathrm{N}$ bond and the $622-$ $647 \mathrm{~cm}^{-1}$, shift shows the presence of $\mathrm{C}=\mathrm{S}$ peak and aliphatic and aromatic peaks were observed in the respective regions. After the complexation, the $\mathrm{C}=\mathrm{S}$ peak was slightly shifted to a lower frequency value which indicates the bond formation between the $\mathrm{C}=\mathrm{S}$ group and the palladium moiety.

3.4. ${ }^{1} H$ NMR Study. The proton NMR spectra of the complexes confirm all the protons present in the complexes. The $\mathrm{N}-\mathrm{H}$ peak was observed in the range of 4.00-4.05 ppm and a singlet peak in the range of 3.69-3.75 shows the $\mathrm{OCH}_{3}$ group and the aromatic protons were observed as multiplets in the range of 6.33-7.63, in the synthesized metallopharmaceutical drugs. The presence of all the protons was confirmed by the proton NMR, which ensures the complex formation between the ligand and the metal atom.

3.5. Cytotoxicity. The results show that concentration of the complexes is directly proportional to \% death of brine shrimps. The maximum $\%$ death is shown by $500 \mu \mathrm{g} / \mathrm{mL}$; the $100 \mu \mathrm{g} / \mathrm{mL}$ concentration showed moderate cytotoxicity and the sample $50 \mu \mathrm{g} / \mathrm{mL}$ showed minimum cytotoxic 
TABLE 4: UV data of $\mathrm{Pd}(\mathrm{II})$ complexes of the type formula $\left[\mathrm{Pd}\left(\mathrm{PR}_{3}\right)(\mathrm{tu}) \mathrm{Cl}_{2}\right]$.

\begin{tabular}{|c|c|c|c|c|c|c|c|}
\hline \multirow{2}{*}{ S. number } & \multirow{2}{*}{ Code of the complex } & \multirow{2}{*}{$\lambda_{\max }$ of the complex } & \multirow{2}{*}{$\lambda_{\max }$ of the complex after DNA addition } & \multicolumn{4}{|c|}{$\mu \mathrm{L}$ of DNA added and absorbance at $\lambda_{\max }$} \\
\hline & & & & $20 \mu \mathrm{L}$ & $40 \mu \mathrm{L}$ & $60 \mu \mathrm{L}$ & $80 \mu \mathrm{L}$ \\
\hline 1 & $\mathrm{C}_{1}$ & 306 & 304 & 1.132 & 1.138 & 1.145 & 1.151 \\
\hline 2 & $\mathrm{C}_{2}$ & 332 & 329 & 0.964 & 0.975 & 0.979 & 0.987 \\
\hline 3 & $\mathrm{C}_{3}$ & 290 & 285 & 1.441 & 1.459 & 1.463 & 1.470 \\
\hline 4 & $\mathrm{C}_{4}$ & 304 & 303 & 1.422 & 1.459 & 1.463 & 1.470 \\
\hline 5 & $\mathrm{C}_{5}$ & 308 & 304 & 0.943 & 0.947 & 0.952 & 0.957 \\
\hline
\end{tabular}

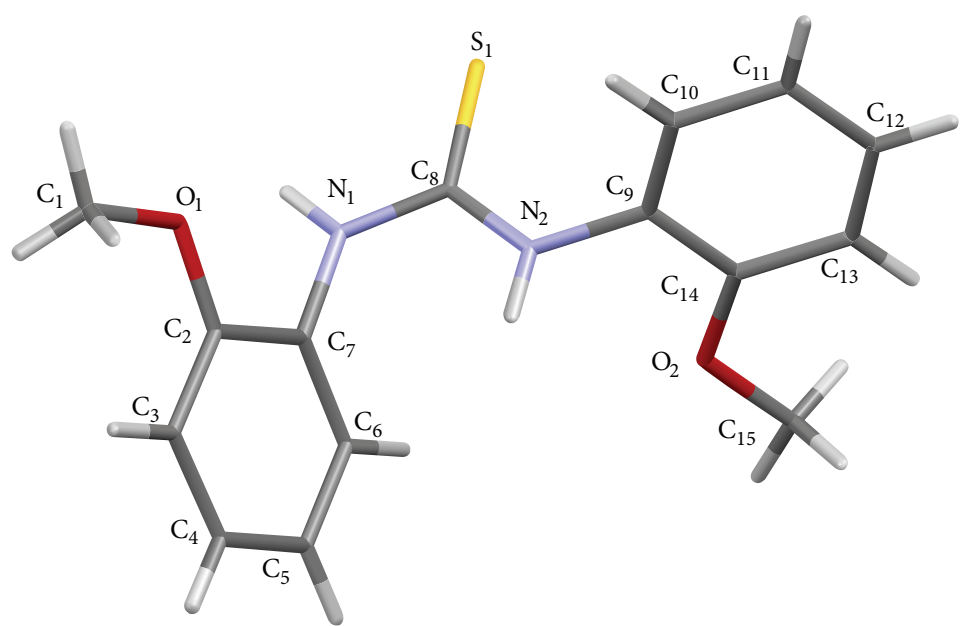

FIGURE 1: The capped sticks diagram of 1,3-bis(2-methoxyphenyl) thiourea. Selected bond lengths $(\AA)$ and angles $\left(\right.$ deg.): $\mathrm{S}_{1}-\mathrm{C}_{8}(1.690(2))$, $\mathrm{N}_{1}-$ $\mathrm{C}_{8}(1.352(2)), \mathrm{N}_{2}-\mathrm{C}_{8}(1.342(3)), \mathrm{N}_{1}-\mathrm{C}_{7}(1.429(2)), \mathrm{N}_{2}-\mathrm{C}_{9}(1.432(3)), \mathrm{O}_{1}-\mathrm{C}_{1}(1.426(3)), \mathrm{O}_{1}-\mathrm{C}_{2}(1.367(3)), \mathrm{O}_{2}-\mathrm{C}_{14}(1.370(3)), \mathrm{O}_{2}-\mathrm{C}_{15}(1.429(3))$, $\mathrm{C}_{15}-\mathrm{O}_{2}-\mathrm{C}_{14}(118.0(2)), \mathrm{C}_{1}-\mathrm{O}_{1}-\mathrm{C}_{2}(118.3(2)), \mathrm{S}_{1}-\mathrm{C}_{8}-\mathrm{N}_{1}(120.2(1)), \mathrm{S}_{1}-\mathrm{C}_{8}-\mathrm{N}_{2}(122.9(1))$, and $\mathrm{N}_{1}-\mathrm{C}_{8}-\mathrm{N}_{2}(116.9(2))$.

activity. The compound $\mathrm{C}_{5}(\mathrm{Pd}(1,3-\mathrm{bis}(2-$ methoxyphenyl) thiourea $\left(\mathrm{PPh}_{2}-\mathrm{o}\right.$-methoxyphenyl $\left.) \mathrm{Cl}_{2}\right)$ is the least cytotoxic while the complex $\mathbf{C}_{2}$ ( $\mathrm{Pd}(1,3$-bis(2-methoxyphenyl) thiourea $)\left(\mathrm{PPh}_{2}\right.$-o-tolyl $\left.) \mathrm{Cl}_{2}\right)$ has exhibited maximum cytotoxicity. The least cytotoxicity of the complex $\mathrm{C}_{5}$ may be assigned to the active methoxy group present in the organophosphine group, which is sufficiently reactive to react with other groups before reaching the target site.

3.6. DNA Interaction. Electronic absorption spectroscopyisone of the versatile techniques to evaluate the interaction mode of complex and DNA molecule. In general, the hypochromism and the red shift reveal the intercalation mode of interaction involving a strong stacking interaction between the aromatic chromophore of the complex and the base pairs of DNA [36]. The data in Table 3 show that there might be some interactions between the drug molecule and DNA, revealed by the brine shrimp activity. Hyperchromism has been observed, which exhibits that the DNA interaction is not the classical intercalation mode, rather it is a groove binding [37]. The groove binding is generally shown by the molecules having unfused aromatic rings linked by bonds with torsional freedom that molecule may adopt conformations which are closely matched with the helical turn of DNA groove [38]. As far as the mixed-ligand Pd(II) complexes are concerned, it is clear that these compounds have unfused rings in the organophosphine ligands that may provide the Vander Waal's interaction in the helical DNA grooves.

3.7. Antibacterial Activity. The synthesized metallodrugs were screened for their antibacterial activity against two gram negative (E. coli and $S$. flexneri) and two gram positive (B. subtilis and $S$. aureus) bacterial strains, the results are presented in Table 2. All the metal complexes are less active than the standard drug Imipenem, however, they have shown moderate antimicrobial activity. The compound 5 (Pd(1,3-bis(2-methoxyphenyl) thiourea) $\left(\mathrm{PPh}_{2}\right.$-o-methoxyphenyl) $\mathrm{Cl}_{2}$ ) has shown maximum activity while compound 3 ( $\mathrm{Pd}\left(1,3\right.$-bis(2-methoxyphenyl) thiourea) $\left(\mathrm{PPh}_{2}-p\right.$-tolyl $\left.) \mathrm{Cl}_{2}\right)$ is the least active compound of all the five synthesized compounds. The antibacterial results indicate that variation in the phosphine ligand changes the activity considerably. Generally, the compounds having the tertiary-butyl, orthotolyl and para-tolyl groups have less activity as compared to the compounds having triphenylphosphine and diphenyl-omethoxyphenyl groups.

\section{Conclusions}

Five heteroleptic Pd(II) complexes have been synthesized and characterized by elemental analysis, FT-IR, and ${ }^{1} \mathrm{H}$ NMR and the ligand thiourea derivative has also been characterized by 
single crystal X-ray diffraction. The synthesized compounds have exhibited moderate antibacterial activity against the four strains of bacteria. The cytotoxicity screening and the DNA binding interaction reveal that the compounds have promising antitumor potential.

\section{Additional Data}

The crystallographic data for the structural analyses of the ligand 1,3-bis(2-methoxyphenyl) thiourea has been deposited with the Cambridge Crystallographic Data Centre, CCDC no. CCDC 929755. Copy of this information may be obtained free of charge from the Director, CCDC, 12 Union Road, Cambridge, CBZ 1EZ, UK (fax: +44 1223336 033; email: deposit@ccdc.cam.ac.uk or http://www.ccdc.cam.ac .uk).

\section{Conflict of Interests}

The authors declare that there is no conflict of interests regarding the publication of this paper.

\section{Acknowledgment}

The authors are highly thankful to the Higher Education Commission of Pakistan for providing the financial assistance for the research work.

\section{References}

[1] J. Kasparkova, O. Vrana, N. Farrell, and V. Brabec, "Effect of the geometry of the central coordination sphere in antitumor trinuclear platinum complexes on DNA binding," Journal of Inorganic Biochemistry, vol. 98, no. 10, pp. 1560-1569, 2004.

[2] V. Brabec and J. Kasparkova, "Modifications of DNA by platinum complexes: relation to resistance of tumors to platinum antitumor drugs," Drug Resistance Updates, vol. 8, no. 3, pp. 131146, 2005.

[3] S. Ahmad, "Platinum-DNA interactions and subsequent cellular processes controlling sensitivity to anticancer platinum complexes," Chemistry and Biodiversity, vol. 7, no. 3, pp. 543566, 2010.

[4] D. Jaramillo, N. J. Wheate, S. F. Ralph, W. A. Howard, Y. Tor, and J. R. Aldrich-Wright, "Polyamide platinum anticancer complexes designed to target specific DNA sequences," Inorganic Chemistry, vol. 45, no. 15, pp. 6004-6013, 2006.

[5] A. Brozovic and M. Osmak, "Activation of mitogen-activated protein kinases by cisplatin and their role in cisplatinresistance," Cancer Letters, vol. 251, no. 1, pp. 1-16, 2007.

[6] S. Moradell, J. Lorenzo, A. Rovira et al., "Platinum complexes of diaminocarboxylic acids and their ethyl ester derivatives: the effect of the chelate ring size on antitumor activity and interactions with GMP and DNA," Journal of Inorganic Biochemistry, vol. 96, no. 4, pp. 493-502, 2003.

[7] I. Kostova, "Platinum complexes as anticancer agents," Recent Patents on Anti-Cancer Drug Discovery, vol. 1, no. 1, pp. 1-22, 2006.

[8] E. Gabano, M. Ravera, and D. Osella, "The drug targeting and delivery approach applied to Pt-antitumour complexes. A coordination point of view," Current Medicinal Chemistry, vol. 16, no. 34, pp. 4544-4580, 2009.

[9] A. Arbuse, M. Font, M. A. Martínez et al., "DNA-cleavage induced by new macrocyclic Schiff base dinuclear $\mathrm{Cu}(\mathrm{I})$ complexes containing pyridyl pendant arms," Inorganic Chemistry, vol. 48, no. 23, pp. 11098-11107, 2009.

[10] H. Mansouri-Torshizi, M. I. Moghaddam, A. Divsalar, and A. A. Saboury, "Diimine platinum(II) and palladium(II) complexes of dithiocarbamate derivative as potential antitumor agents: synthesis, characterization, cytotoxicity, and detail DNA-binding studies," Journal of Biomolecular Structure and Dynamics, vol. 26, no. 5, pp. 575-586, 2009.

[11] K. Lemma, T. Shi, and L. I. Elding, "Kinetics and mechanism for rreduction of the anticancer prodrug trans,trans, trans$\left[\mathrm{PtCl}_{2}(\mathrm{OH})_{2}\left(\mathrm{c}-\mathrm{C}_{6} \mathrm{H}_{11} \mathrm{NH}_{2}\right)\left(\mathrm{NH}_{3}\right)\right]$ (JM335) by thiols," Inorg. Chem, vol. 39, pp. 1728-1734, 2000.

[12] M. D. Hall and T. W. Hambley, "Platinum(IV) antitumour compounds: their bioinorganic chemistry," Coordination Chemistry Reviews, vol. 232, no. 1-2, pp. 49-67, 2002.

[13] M. D. Hall, H. R. Mellor, R. Callaghan, and T. W. Hambley, "Basis for design and development of platinum(IV) anticancer complexes," Journal of Medicinal Chemistry, vol. 50, no. 15, pp. 3403-3411, 2007.

[14] K. R. Barnes, A. Kutikov, and S. J. Lippard, "Synthesis, characterization, and cytotoxicity of a series of estrogen-tethered platinum(IV) complexes," Chemistry and Biology, vol. 11, no. 4, pp. 557-564, 2004.

[15] K. Sakai, Y. Tomita, T. Ue et al., "Syntheses, antitumor activity, and molecular mechanics studies of cis- $\mathrm{PtCl}_{2}(\mathrm{pzH})_{2}(\mathrm{pzH}=$ pyrazole) and related complexes. Crystal structure of a novel Magnus-type double-salt $\left[\mathrm{Pt}(\mathrm{pzH})_{4}\right]\left[\mathrm{PtCl}_{4}\right]\left[\text { cis- } \mathrm{PtCl}_{2}(\mathrm{pzH})_{2}\right]_{2}$ involving two perpendicularly aligned $1 \mathrm{D}$ chains," Inorganica Chimica Acta, vol. 297, no. 1-2, pp. 64-71, 2000.

[16] K. Sakai and H. Ozawa, "Homogeneous catalysis of platinum(II) complexes in photochemical hydrogen production from water," Coordination Chemistry Reviews, vol. 251, no. 21-24, pp. 27532766, 2007.

[17] K. Husain, M. Abid, and A. Azam, "Novel Pd(II) complexes of 1$\mathrm{N}$-substituted 3-phenyl-2-pyrazoline derivatives and evaluation of antiamoebic activity," European Journal of Medicinal Chemistry, vol. 43, no. 2, pp. 393-403, 2008.

[18] A. Boixassa, J. Pons, X. Solans, M. Font-Bardia, and J. Ros, "Reaction of platinum(II) derivatives with 1-hydroxyalkyl3,5-dimethylpyrazole ligands. Cleavage of the $\mathrm{N}(\mathrm{pz}) \mathrm{C}\left(\mathrm{sp}^{3}\right)$ bond. X-ray crystal structure of cis- $\left[\mathrm{PtCl}_{2}\left(\mathrm{HL}^{2}\right)_{2}\right]\left(\mathrm{HL}^{2}=1-\right.$ (2- hydroxyethyl)-3,5-dimethylpyrazole) and trans- $\left[\mathrm{PtCl}_{2}(\mathrm{dm}\right.$ $\mathrm{pz})_{2}$ ] (dmpz=3,5-dimethylpyrazole)," Inorganica Chimica Acta, vol. 355, pp. 254-263, 2003.

[19] E. Budzisz, U. Krajewska, M. Rozalski, A. Szulawska, M. Czyz, and B. Nawrot, "Biological evaluation of novel Pt(II) and Pd(II) complexes with pyrazole-containing ligands," European Journal of Pharmacology, vol. 502, no. 1-2, pp. 59-65, 2004.

[20] D. S. Pilch, S. U. Dunham, E. R. Jamieson, S. J. Lippard, and K. J. Breslauer, "DNA sequence context modulates the impact of a cisplatin 1,2-d(GpG) intrastrand cross-link on the conformational and thermodynamic properties of duplex DNA," Journal of Molecular Biology, vol. 296, no. 3, pp. 803-812, 2000.

[21] E. R. Jamieson and S. J. Lippard, "Structure, recognition, and processing of cisplatin-DNA adducts," Chemical Reviews, vol. 99, no. 9, pp. 2467-2498, 1999. 
[22] Z. Nagy and I. Sovago, "Thermodynamic and structural characterisation of the complexes formed in the reaction of $[\mathrm{Pd}(\mathrm{en})$ $\left.\left(\mathrm{H}_{2} \mathrm{O}\right)_{2}\right]^{2+}$ and $\left[\mathrm{Pd}(\text { pic })\left(\mathrm{H}_{2} \mathrm{O}\right)_{2}\right]^{2+}$ with $\mathrm{N}$-alkyl nucleobases and $\mathrm{N}$-acetyl amino acids," Journal of the Chemical Society, Dalton Transactions, pp. 2467-2475, 2001.

[23] A. A. El-Sherif, M. M. Shoukry, and R. van Eldik, "Complexformation reactions and stability constants for mixed-ligand complexes of diaqua(2-picolylamine)palladium(II) with some bio-relevant ligands," Dalton Transactions, no. 7, pp. 1425-1432, 2003.

[24] S. Zhu, A. Matilla, J. M. Tercero, V. Vijayaragavan, and J. A. Walmsley, "Binding of palladium(II) complexes to guanine, guanosine or guanosine $5^{\prime}$-monophosphate in aqueous solution: potentiometric and NMR studies," Inorganica Chimica Acta, vol. 357, no. 2, pp. 411-420, 2004.

[25] J. M. Tercero-Moreno, A. Matilla-Hernández, S. GonzálezGarcía, and J. Niclós-Gutiérrez, "Hydrolytic species of the ion cis-diaqua(ethylenediamine)palladium(II) complex and of cisdichloro(ethylenediamine)palladium(II): fitting its equilibrium models in aqueous media with or without chloride ion," Inorganica Chimica Acta, vol. 253, no. 1, pp. 23-29, 1996.

[26] N. Summa, W. Schiessl, R. Puchta, N. van Eikema Hommes, and R. van Eldik, "Thermodynamic and kinetic studies on reactions of $\mathrm{Pt}(\mathrm{II})$ complexes with biologically relevant nucleophiles," Inorganic Chemistry, vol. 45, no. 7, pp. 2948-2959, 2006.

[27] H. Khan, M. Aziz, C. Neuhausen, G. Murtaza, and F. Shaheen, "[(Methylcarbamothioyl)disulfanyl]methyl N-methylcarbamodithioate," Acta Crystallographica E: Structure Reports Online, vol. 66, no. 10, p. o2671, 2010.

[28] H. Khan, H. Badshah, Z. Rehman et al., "New dimeric and supramolecular mixed ligand Palladium(II) dithiocarbamates as potent DNA binders," Polyhedrone, vol. 39, no. 1, pp. 1-8, 2012.

[29] Bruker APEX 2 Version 2.0.2, Bruker AXS, Madison, Wis, USA, 2005.

[30] Bruker SAINT Version 7.0.7a, Bruker AXS Inc., Madison, Wis, USA, 2003.

[31] G. Murtaza, A. Badshah, M. Said et al., "Urease inhibition and anti-leishmanial assay of substituted benzoylguanidines and their copper(ii) complexes," Dalton Transactions, vol. 40, no. 36, pp. 9202-9211, 2011.

[32] A. Rahman, M. I. Choudhary, and W. J. Thomsen, Bioassay Techniques for Drug Development, Harward Academic Press, Amsterdam, The Netherlands, 2001.

[33] H. Khan, A. Badshah, G. Murtaz et al., "Synthesis, characterization and anticancer studies of mixed ligand dithiocarbamate palladium(II) complexes," European Journal of Medicinal Chemistry, vol. 46, no. 9, pp. 4071-4077, 2011.

[34] F. H. Allen, O. Kennard, D. G. Watson, L. Brammer, A. G. Orpen, and R. Taylor, "Tables of bond lengths determined by X-ray and neutron diffraction. Part 1 . Bond lengths in organic compounds," Journal of the Chemical Society, Perkin Transactions 2, no. 12, pp. S1-S19, 1987.

[35] D. Fregona, L. Giovagnini, L. Ronconi et al., "Pt(II) and Pd(II) derivatives of ter-butylsarcosinedithiocarbamate: synthesis, chemical and biological characterization and in vitro nephrotoxicity," Journal of Inorganic Biochemistry, vol. 93, no. 3-4, pp. 181-189, 2003.

[36] V. A. Bloomfield, D. M. Carothers, and I. Tinoco Jr., Physical Chemistry of Nucleic Acids, Harper and Row, New York, NY, USA, 1974.

[37] R. Vijayalakshmi, M. Kanthimathi, V. Subramanian, and B. U. Nair, "Interaction of DNA with $\left[\mathrm{Cr}(\right.$ Schiff base $\left.)\left(\mathrm{H}_{2} \mathrm{O}\right)_{2}\right] \mathrm{ClO}_{4}$,"
Biochimica et Biophysica Acta: General Subjects, vol. 1475, no. 2, pp. 157-162, 2000.

[38] L. Strekowski and B. Wilson, "Noncovalent interactions with DNA: an overview," Mutation Research: Fundamental and Molecular Mechanisms of Mutagenesis, vol. 623, no. 1-2, pp. 313, 2007. 

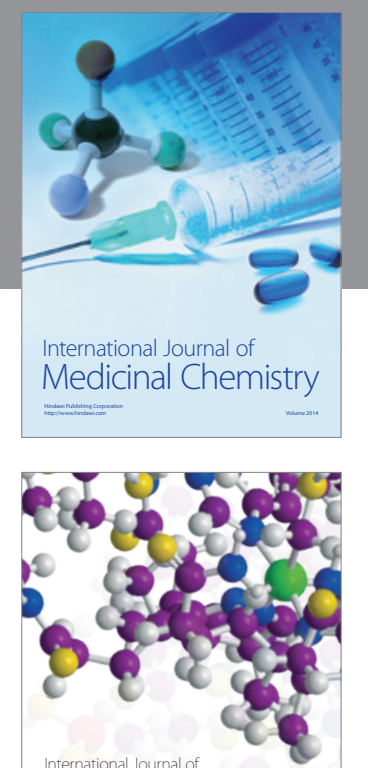

\section{Carbohydrate} Chemistry

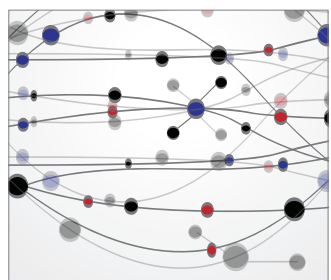

The Scientific World Journal
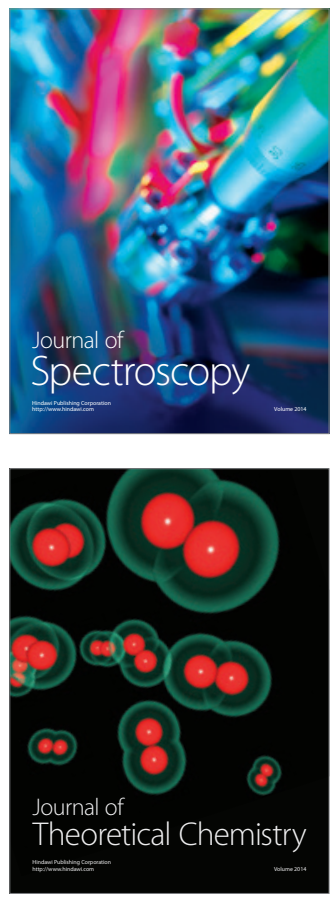
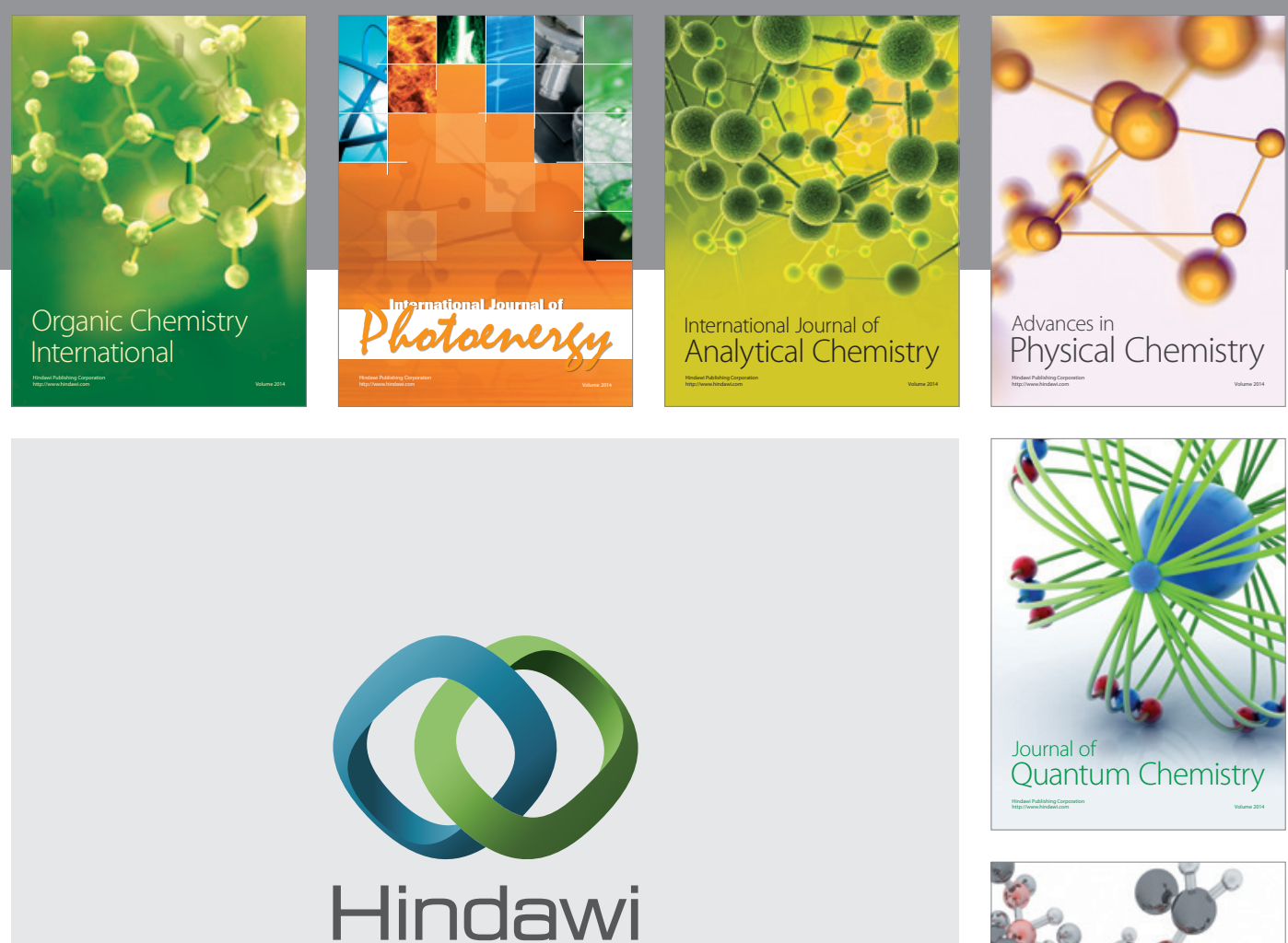

Submit your manuscripts at

http://www.hindawi.com

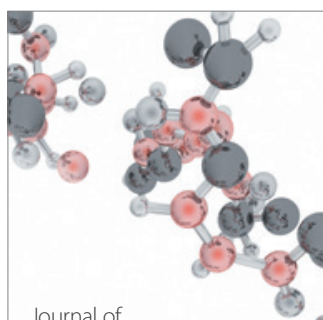

Analytical Methods

in Chemistry

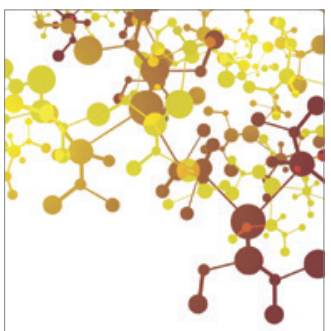

Journal of

Applied Chemistry

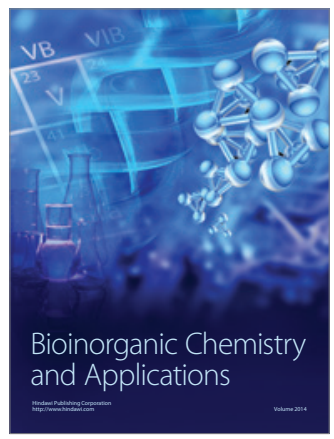

Inorganic Chemistry
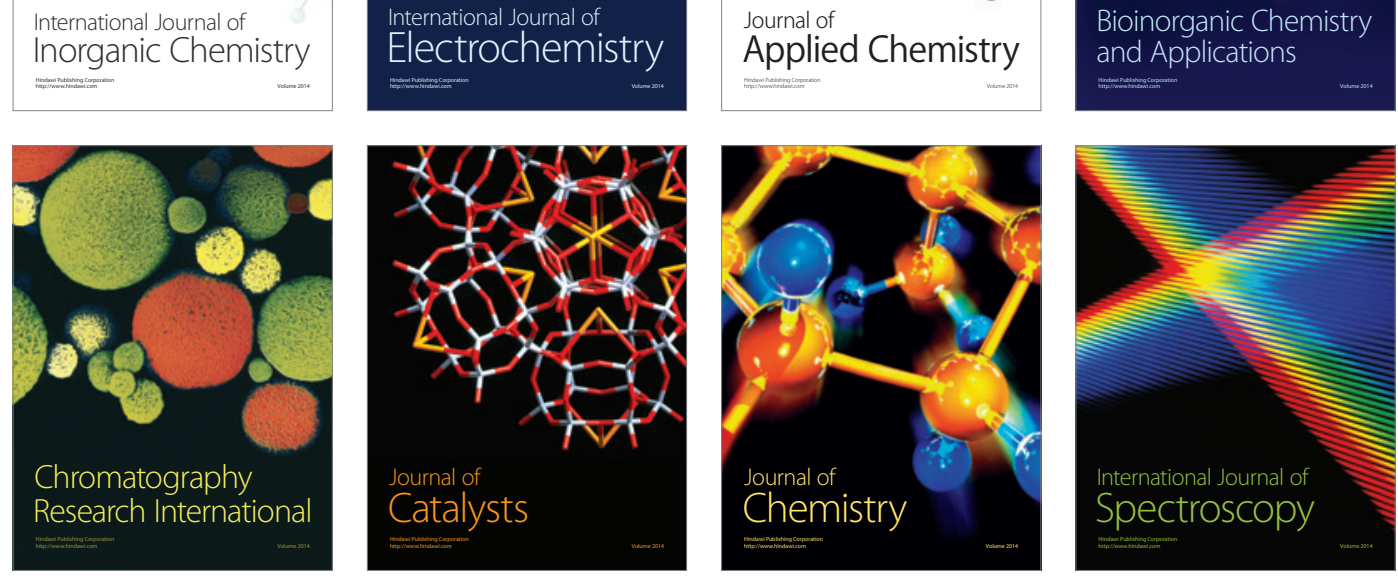